\title{
Water saving through international trade of agricultural products
}

\author{
A. K. Chapagain ${ }^{1,2}$, A. Y. Hoekstra ${ }^{2}$, and H. H. G. Savenije ${ }^{1,3}$ \\ ${ }^{1}$ UNESCO-IHE Institute for Water Education, Delft, The Netherlands \\ ${ }^{2}$ Group of Water Engineering and Management, Faculty of Engineering Technology, University of Twente, Enschede, The \\ Netherlands \\ ${ }^{3}$ Faculty of Civil Engineering and Geosciences, Delft University of Technology, Delft, The Netherlands
}

Received: 7 September 2005 - Published in Hydrol. Earth Syst. Sci. Discuss.: 4 November 2005

Revised: 18 May 2006 - Accepted: 18 May 2006 - Published: 30 June 2006

\begin{abstract}
Many nations save domestic water resources by importing water-intensive products and exporting commodities that are less water intensive. National water saving through the import of a product can imply saving water at a global level if the flow is from sites with high to sites with low water productivity. The paper analyses the consequences of international virtual water flows on the global and national water budgets. The assessment shows that the total amount of water that would have been required in the importing countries if all imported agricultural products would have been produced domestically is $1605 \mathrm{Gm}^{3} / \mathrm{yr}$. These products are however being produced with only $1253 \mathrm{Gm}^{3} / \mathrm{yr}$ in the exporting countries, saving global water resources by 352 $\mathrm{Gm}^{3} / \mathrm{yr}$. This saving is 28 per cent of the international virtual water flows related to the trade of agricultural products and 6 per cent of the global water use in agriculture. National policy makers are however not interested in global water savings but in the status of national water resources. Egypt imports wheat and in doing so saves $3.6 \mathrm{Gm}^{3} / \mathrm{yr}$ of its national water resources. Water use for producing export commodities can be beneficial, as for instance in Cote d'Ivoire, Ghana and Brazil, where the use of green water resources (mainly through rain-fed agriculture) for the production of stimulant crops for export has a positive economic impact on the national economy. However, export of $28 \mathrm{Gm}^{3} / \mathrm{yr}$ of national water from Thailand related to rice export is at the cost of additional pressure on its blue water resources. Importing a product which has a relatively high ratio of green to blue virtual water content saves global blue water resources that generally have a higher opportunity cost than green water.
\end{abstract}

Correspondence to: A. Y. Hoekstra

(a.y.hoekstra@utwente.nl)

\section{Introduction}

The most direct positive effect of virtual water trade is the water savings it generates in the countries or the regions that import the products. This effect has been widely discussed in virtual water studies since the nineties (Allan, 1999; Hoekstra, 2003). These national water savings are equal to the import volumes multiplied by the volumes of water that would have been required to produce the commodities domestically. However, virtual water trade does not only generate water savings for importing countries, it also means water "losses" for the exporting countries (in the sense that the water cannot be used anymore for other purposes in the exporting countries). The global net effect of virtual water trade between two nations will depend on the actual water volume used in the exporting country in comparison to the water volume that would have been required to produce a commodity in the importing country. There will be net water saving, if the trade is from countries with relatively high water productivity (i.e. commodities have a low virtual water content) to countries with low water productivity (commodities with a high virtual water content). There can be net additional consumption of water if the transfer is from low to high productive sites. The saving can also be realised with transfer of products from low to high productive periods by storage of food, which can be a more efficient and more environmentally friendly way of bridging the dry periods than building large dams for temporary water storage (Renault, 2003).

Virtual water trade between nations is one means of increasing the efficiency of water use in the world. As Hoekstra and Hung $(2002,2005)$ argue, there are three levels of water use efficiency. At a local level, that of the water user, water use efficiency can be increased by charging prices based on full marginal cost, stimulating water-saving technology, and creating awareness among the water users on the detrimental impacts of water abstractions. At the catchment or river basin level, water use efficiency can be enhanced by re-allocating

Published by Copernicus GmbH on behalf of the European Geosciences Union. 
water to those purposes with the highest marginal benefits. Finally, at the global level, water use efficiency can be increased if nations use their comparative advantage or disadvantage in terms of water availability to encourage or discourage the use of domestic water resources for producing export commodities (respectively stimulate export or import of virtual water). Whereas much research efforts have been dedicated to study water use efficiency at the local and river basin level, little efforts have been done to analyse water use efficiency at global level.

According to the theory of comparative advantage, nations can gain from trade if they concentrate or specialize in the production of goods and services for which they have a comparative advantage, while importing goods and services for which they have a comparative disadvantage (Wichelns, 2001, 2004). The pros and cons of the virtual water trade should be weighed including the opportunity cost of the associated water. Some trade flows may be more beneficial than others purely because of the higher opportunity cost of the water being saved. It is relevant for instance to look whether water saved is blue or green water. Green water is the productive use of rainfall in crop production, which, in general, has a lower opportunity cost compared to the blue water use (i.e. irrigation).

The average global volume of virtual water flows related to the international trade in agricultural products was $1263 \mathrm{Gm}^{3} / \mathrm{yr}$ in the period 1997-2001 (Chapagain and Hoekstra, 2004). This estimate is based on the virtual water content of the products in the exporting countries. It would be interesting to see the volume of virtual water traded internationally based on the virtual water content of the products in the importing countries. Zimmer and Renault (2003) estimated this as $1340 \mathrm{Gm}^{3} / \mathrm{yr}$ related to the international trade in crop and livestock products in the year 2000. These studies only present a partial view of the global or national savings.

An estimate of global virtual water trade and resulting global water saving was done by Oki et al. (2003) and Oki and Kanae (2004). They estimated the global sum of virtual water exports on the basis of the virtual water content of the products in the exporting countries $\left(683 \mathrm{Gm}^{3} / \mathrm{yr}\right)$ and the global sum of virtual water imports on the basis of the virtual water content of the products in the importing countries $\left(1138 \mathrm{Gm}^{3} / \mathrm{yr}\right)$. This saves $455 \mathrm{Gm}^{3} / \mathrm{yr}$ as a result of food trade. Their study is severely limited with respect to the methodology followed in calculating the virtual water content of a product. First, they have assumed a constant global average crop water requirement throughout the world, being $15 \mathrm{~mm} /$ day for rice and $4 \mathrm{~mm} /$ day for maize, wheat and barley. Thus the climatic factor, which plays a major role in the crop water requirement of a crop, is completely neglected. Secondly, they did not take into account the role of the crop coefficient, which is the major limiting factor determining the evaporation from a crop at different stages of crop growth. The global virtual water flows and the resulting water savings as calculated in these studies are limited to the international trade of four major crops (maize, wheat, rice and barley) only. Another study on global water saving as a result of trade is De Fraiture et al. (2004), who estimate that international cereal trade reduces global water use by $164 \mathrm{Gm}^{3} / \mathrm{yr}$.

The purpose of this study is to quantify and analyse national and global water savings and losses for the period 1997-2001 with proper accounting of climate, yield, and cropping pattern per crop per country. The study covers the international trade of all major crop and livestock products. The study is focused on quantifying water savings and losses in physical units. The calculated physical savings and losses cannot be interpreted in a straightforward manner in terms of economic savings or losses. The calculated water savings and losses can be valued positive or negative in an economic sense depending on the wider context only, because the economic efficiency of international trade of agricultural commodities depends on a lot more factors than water alone, such as scarcity of land, labour, knowledge and capital, competitiveness (comparative advantage) in certain types of production, domestic subsidies, export subsidies and import taxes and quotas.

\section{Method}

The virtual water content of a product is calculated using the methodology as developed by Hoekstra and Hung (2002, 2005) and Chapagain and Hoekstra (2003, 2004). First the virtual water content $\left(\mathrm{m}^{3} /\right.$ ton $)$ of the primary crop is calculated based on crop water requirement and yield in the producing country. The crop water requirement is calculated using the methodology developed by FAO (Allen et al., 1998). Country average data for actual vapour pressure, daily maximum temperature, daily minimum temperature and percentage cloud cover have been taken from the on-line database of the Tyndall Centre for Climate Change and Research (Mitchell, 2004). The data available here are averages over the period 1961-1990. Data on average elevation, latitude and wind speed have been taken from the database CLIMWAT (FAO, 2004a). Crop coefficients for different crops and crop calendars have been taken from FAO (Allen et al., 1998; FAO, 2004b). Data on average crop yield (ton/ha) and annual production (ton/yr) per primary crop per country have been taken from the on-line database of FAO (FAO, 2004c).

The virtual water content ( $\mathrm{m}^{3} /$ ton) of live animals has been calculated based on the virtual water content of their feed and the volumes of drinking and service water consumed during their lifetime. The virtual water content of processed products is calculated based on product fractions (ton of crop product obtained per ton of primary crop or live animal) and value fractions (the market value of one crop or livestock product divided by the aggregated market value of all products derived from one primary crop or live animal). 
USA

Virtual water content, $V_{e}=1275 \mathrm{~m}^{3} /$ ton

Virtual water content, $V_{i}=2182 \mathrm{~m}^{3} /$ ton

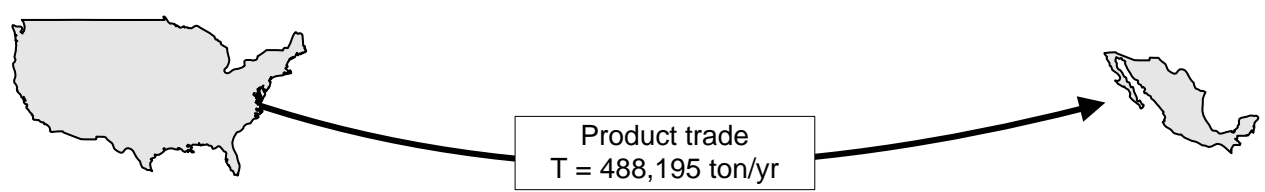

National water loss

$$
\begin{aligned}
\Delta S_{n} & =V_{e} \times T \\
& =1275 \times 488,195
\end{aligned}
$$$$
=0.62 \times 10^{9} \mathrm{~m}^{3} / \mathrm{yr}
$$

$$
\begin{aligned}
& \text { Global water saving } \\
& \begin{aligned}
\Delta S_{g} & =T\left(V_{i}-V_{e}\right) \\
& =488,195 \times(2182-1275) \\
& =\mathbf{0 . 4 4} \times 10^{9} \mathbf{m}^{3} / \mathbf{y r}
\end{aligned}
\end{aligned}
$$

$$
\begin{aligned}
& \text { National water saving } \\
& \begin{aligned}
\Delta S_{n} & =V_{i} \times T \\
& =2182 \times 488,195 \\
& =1.06 \times 10^{9} \mathrm{~m}^{3} / \mathrm{yr}
\end{aligned}
\end{aligned}
$$

Fig. 1. An example of global water saving with the import of husked rice in Mexico from USA.

Thailand

Virtual water content, $V_{e}=5455 \mathrm{~m}^{3} /$ ton
Indonesia

Virtual water content, $V_{i}=3103 \mathrm{~m}^{3} /$ ton

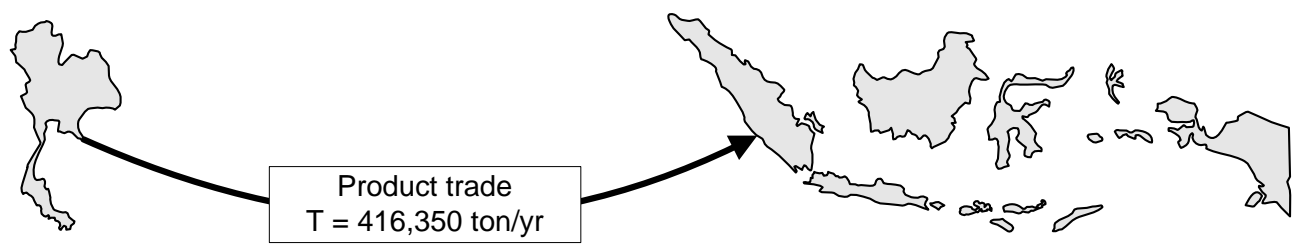

$$
\begin{aligned}
& \text { National water loss } \\
& \begin{aligned}
\Delta S_{n} & =V_{e} \times T \\
& =5455 \times 416,350 \\
& =\mathbf{2 . 2 7} \times 10^{9} \mathbf{~ m}^{3} / \mathbf{y r}
\end{aligned}
\end{aligned}
$$

$$
\begin{aligned}
& \text { Global water saving } \\
& \begin{aligned}
\Delta S_{g} & =T\left(V_{i}-V_{e}\right) \\
& =416,350 \times(3103-5455) \\
& =-0.98 \times 10^{9} \mathrm{~m}^{3} / \mathrm{yr}
\end{aligned}
\end{aligned}
$$

$$
\begin{aligned}
& \text { National water saving } \\
& \begin{aligned}
\Delta S_{n} & =V_{i} \times T \\
& =3103 \times 416,350 \\
& =1.29 \times 10^{9} \mathrm{~m}^{3} / \mathrm{yr}
\end{aligned}
\end{aligned}
$$

Fig. 2. An example of global water loss with the import of broken rice in Indonesia from Thailand.

The product fractions have been taken from the commodity trees in FAO (2003). The value fractions have been calculated based on the market prices of the various products. The global average market prices of the different products for the period 1997-2001 have been calculated using trade data from the International Trade Centre (ITC, 2004).

The national water saving $\Delta S_{n}\left(\mathrm{~m}^{3} / \mathrm{yr}\right)$ of a country $n_{i}$ as a result of trade of product $p$ is:

$\Delta S_{n}\left[n_{i}, p\right]=V\left[n_{i}, p\right] \times I\left[n_{i}, p\right]-V\left[n_{i}, p\right] \times E\left[n_{i}, p\right](1)$

where $V$ is the virtual water content $\left(\mathrm{m}^{3} /\right.$ ton) of the product $p$ in country $n_{i}, I$ the amount of product $p$ imported (ton/yr) and $E$ is the amount of product exported (ton/yr). Obviously, $\Delta S_{n}$ can have a negative sign, which means a net water loss instead of a saving.

The global water saving $\Delta S_{g}\left(\mathrm{~m}^{3} / \mathrm{yr}\right)$ through the trade of a product $p$ from an exporting country $n_{e}$ to an importing country $n_{i}$, is:

$\Delta S_{g}\left[n_{e}, n_{i}, p\right]=T\left[n_{e}, n_{i}, p\right] \times\left(V\left[n_{i}, p\right]-V\left[n_{e}, p\right]\right)$

where $T$ is the amount of trade (ton/yr) between the two countries. The global saving is thus obtained as the differ- ence between the water productivities of the trading partners. The total global water saving can be obtained by summing up the global savings of all trades $\Delta S_{g}$. By definition, the total global water saving is also equal to the sum of the national savings of all countries $\Delta S_{n}$.

The case of global water saving is illustrated with an example of the import of husked rice in Mexico from the USA in Fig. 1. The case of global water loss is shown with an example of export of broken rice from Thailand to Indonesia in Fig. 2. For the computation of the total water saving that is made by international trade of agricultural products, the calculation has been carried out for 285 crop products and 123 livestock products as reported in the database PCTAS (ITC, 2004) which covers international trade between 243 countries for 1997-2001.

\section{National water savings}

A large number of countries are saving their national water resources with the international trade of agricultural products. Japan saves $94 \mathrm{Gm}^{3} / \mathrm{yr}$ from its domestic 


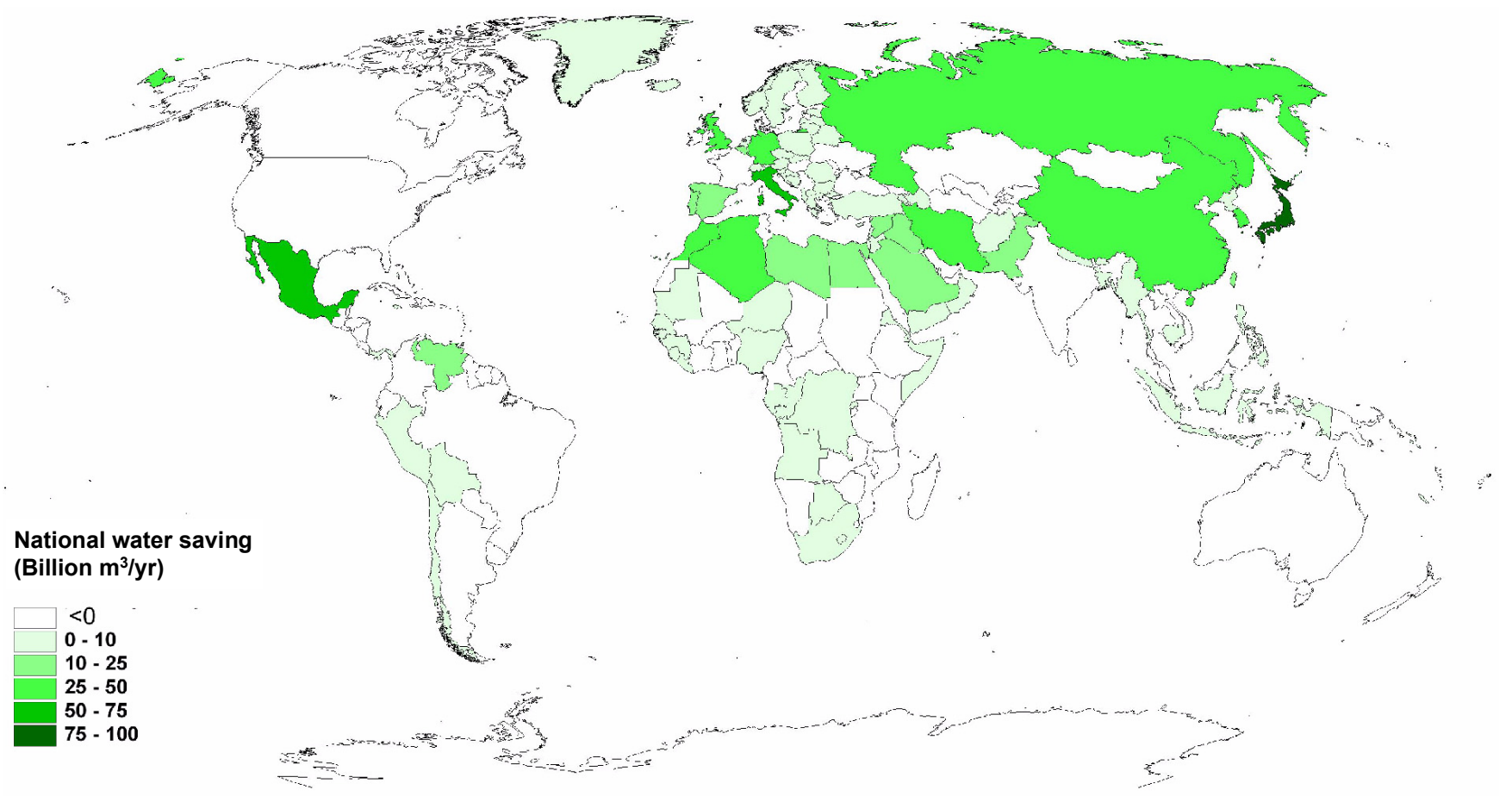

Fig. 3. National water savings related to international trade of agricultural products. Period 1997-2001.

Table 1. Nations with the largest net water saving as a result of international trade of agricultural products. Period 1997-2001.

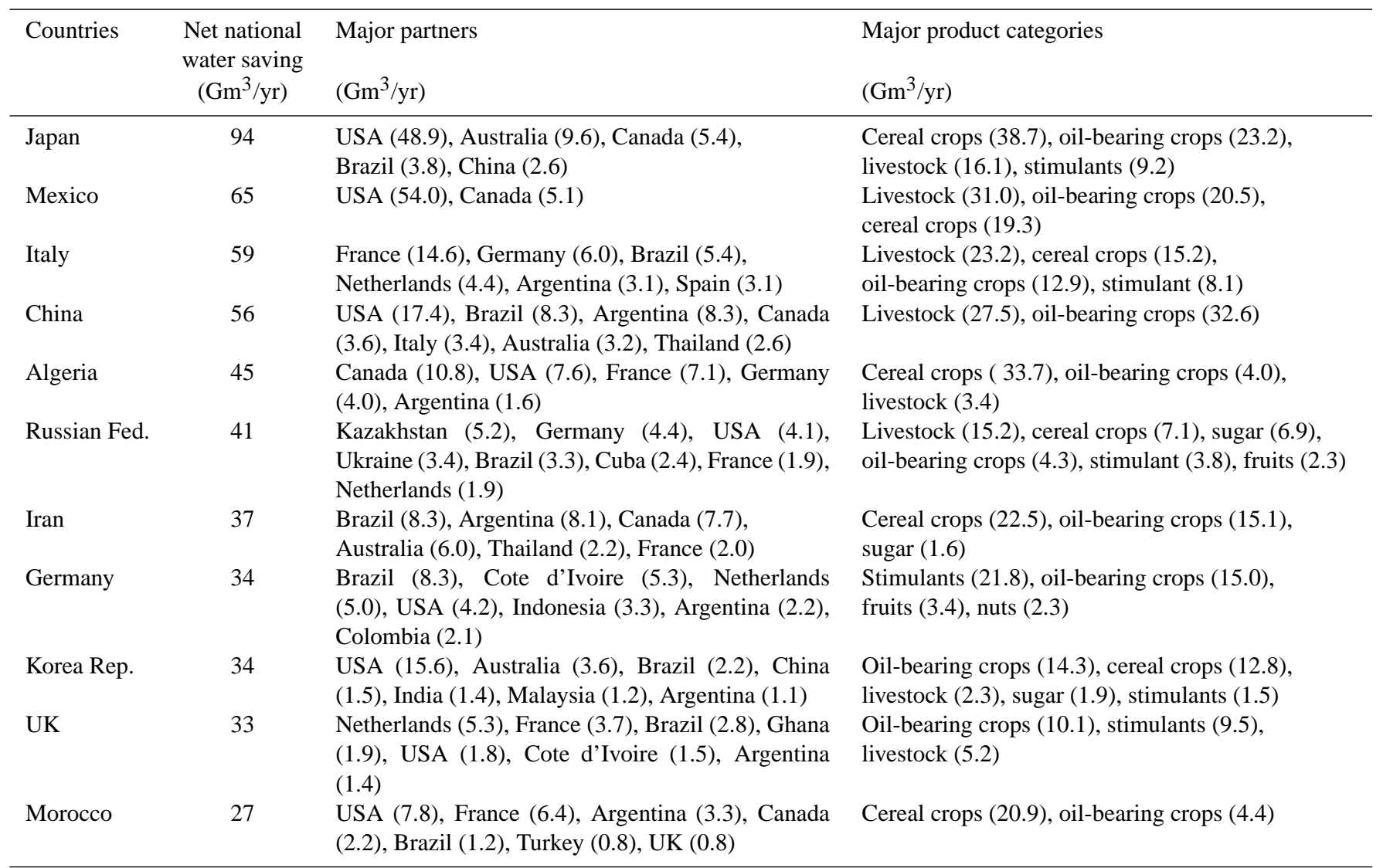




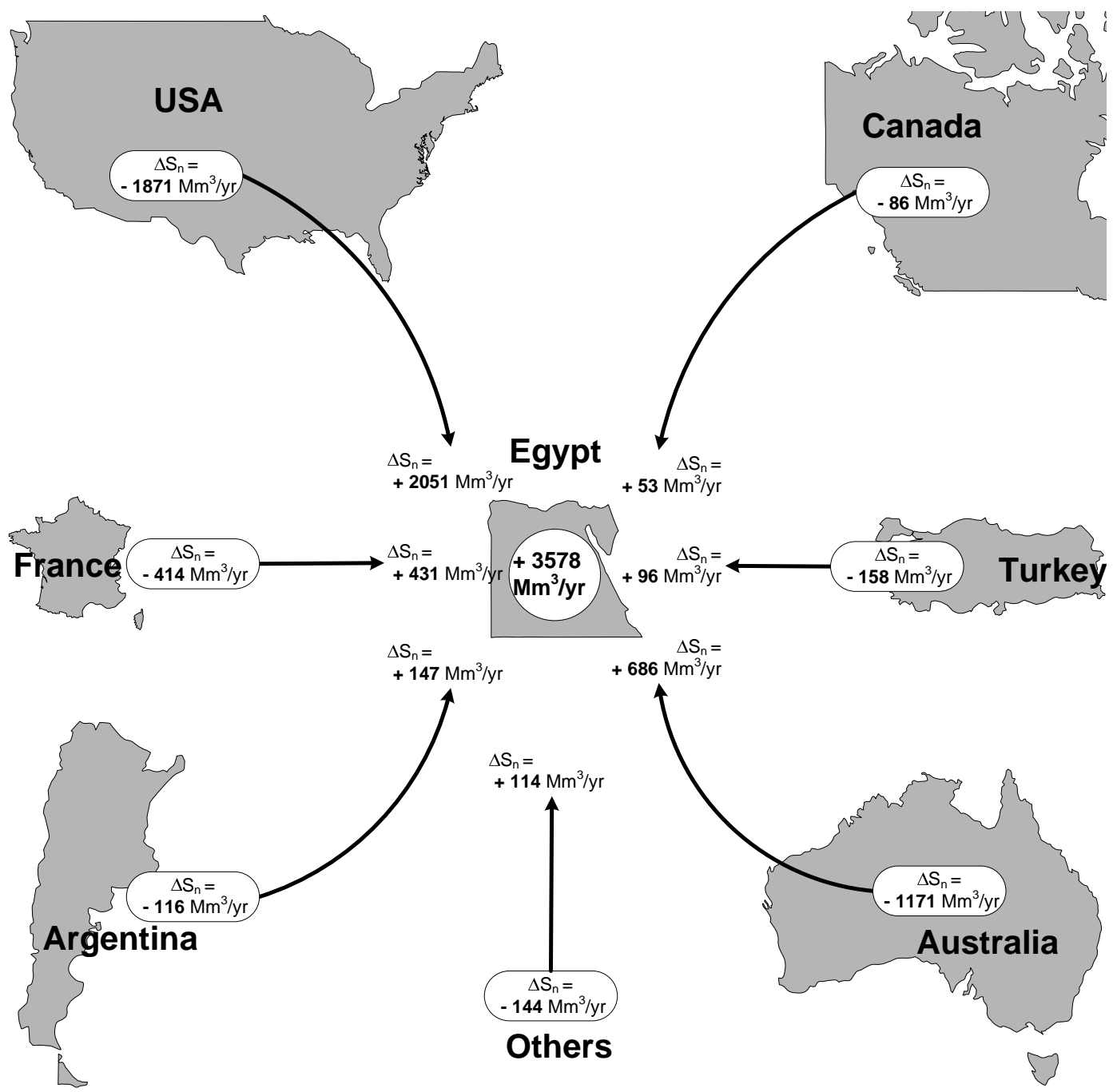

Fig. 4. National water saving related to the net wheat import of Egypt. Period 1997-2001.

water resources, Mexico $65 \mathrm{Gm}^{3} / \mathrm{yr}$, Italy $59 \mathrm{Gm}^{3} / \mathrm{yr}$, China $56 \mathrm{Gm}^{3} / \mathrm{yr}$ and Algeria $45 \mathrm{Gm}^{3} / \mathrm{yr}$. The global picture of national savings is presented in Fig. 3. The driving forces behind international trade of water-intensive products can be water scarcity in the importing countries, but often other factors such as scarcity of fertile land or other resources play a decisive role (Yang et al., 2003). As a result, realised national water savings can only partially be explained through national water scarcity.

The national water saving has different implications per country. Though Germany saves $34 \mathrm{Gm}^{3} / \mathrm{yr}$, it may be less important from a national policy making perspective because the major products behind the saving are stimulant crops (tea, coffee and cocoa) which Germany would otherwise not produce itself. If the import of stimulants is reduced, it may not create any additional pressure on the water resources in Germany. However, for Morocco, where import of cereal crop products is the largest national water saver, shifting from im- port to domestic production would create an additional pressure of $21 \mathrm{Gm}^{3} / \mathrm{yr}$ on its national water resources. The nations that save most water through international trade of agricultural products and the main products behind the savings are presented in Table 1.

For an importing country it is not relevant whether products are consuming green or blue water in the exporting country. The importing country is more interested to see what volume and kind of water is being saved from its own resources by the import. And it is further important to see whether the water thus saved has higher marginal benefits than the additional cost to import these products.

As an example, Fig. 4 shows the national water saving of Egypt as a result of the import of wheat. In Egypt, the mean rainfall is only $18 \mathrm{~mm} / \mathrm{yr}$. Almost all agriculture in Egypt is irrigated. At present, Egypt and Sudan base their water resources plan on the agreed division of water by the 1959 Nile water agreement between Sudan and Egypt. However, future 


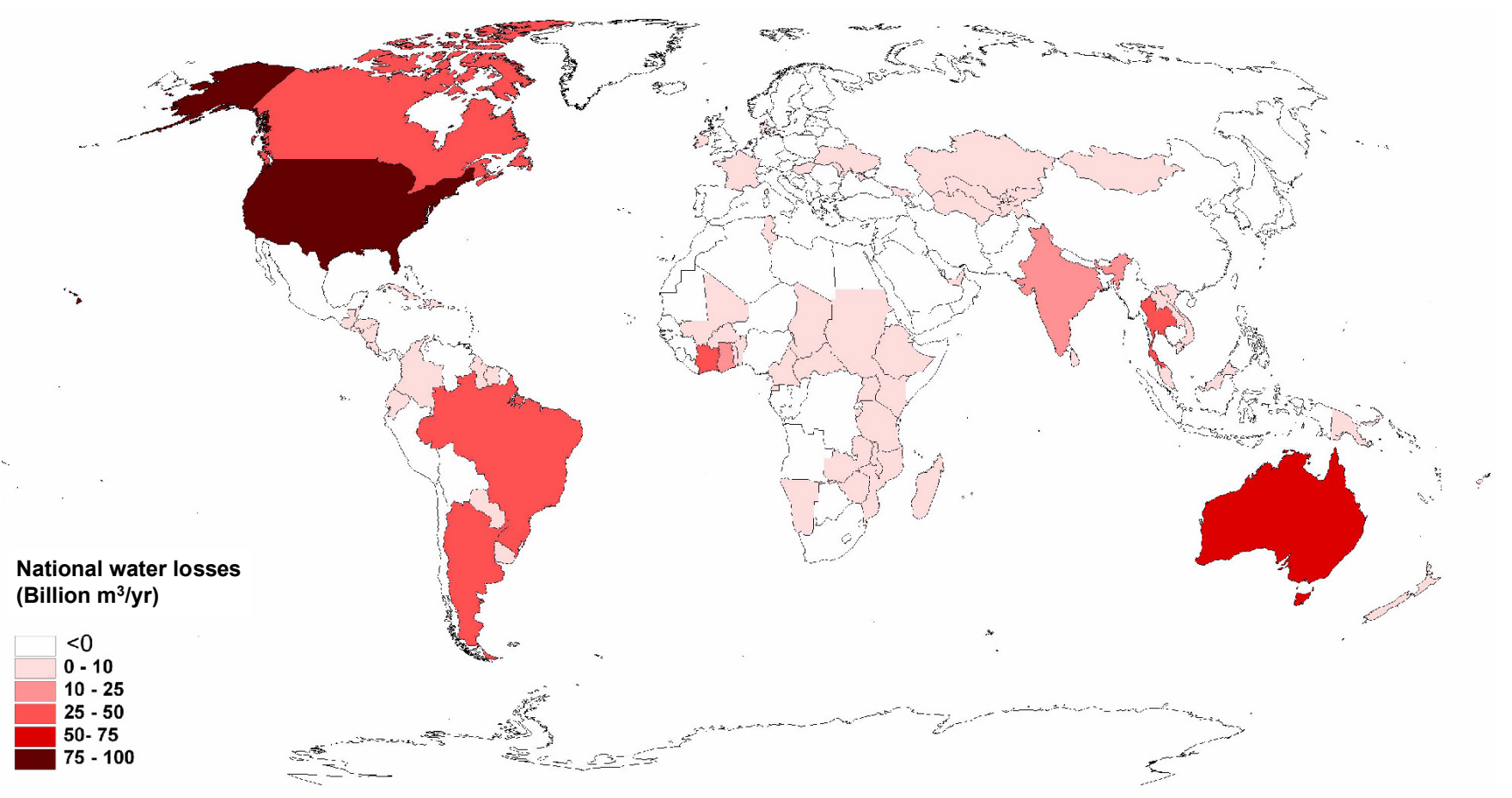

Fig. 5. National water losses related to international trade of agricultural products. Period 1997-2001.

developments in upstream countries will have to be taken into account. Disputes over the distribution of water of the Nile could become a potential source of conflict and contention. The expansion of irrigation in the basin will require basinwide cooperation in the management of water resources to meet increasing demands and to face the associated environmental consequences. In this context, the import of wheat in Egypt is contributing to a national water saving of $3.6 \mathrm{Gm}^{3} / \mathrm{yr}$ which is about seven percent of the total volume of water Egypt is entitled to according to the 1959 agreement. The national saving is made with the investment of foreign exchange of 593 million US $\$ / y r$ (ITC, 2004). Hence, from an economic point of view, the opportunity cost of the resources being saved (such as land, water and labour) should be more or at least equal to the price paid for it. If the opportunity cost of land and labour approaches zero, the opportunity cost of water being saved should be more than $0.17 \mathrm{US} \$ \mathrm{~m}^{3}$. But the import of wheat in Egypt should be assessed including other factors of production such as land and labour. In Egypt fertile land is also a major scarce resource. The pressure to increase the land area with reclamation is released to some extent by the wheat import but on the other hand the import is made at the cost of employment lost. Greenaway et al. (1994) and Wichelns (2001) have shown that the production of wheat has a comparative disadvantage in Egypt. As the saving is completely in blue water, the marginal utility of the saved water may justify the import economically.

\section{National water losses}

Whereas import of agricultural products implies that national water resources are saved, export of agricultural products entails that national water resources are lost. The term "national water loss" is used in this paper to refer to the fact that water used for producing commodities that are consumed by people in other countries is not available anymore for in-country purposes. The term "water loss" is used here as the opposite of "water saving". As explained earlier, the terms "loss" and "saving" are not to be interpreted in terms of economic loss or saving, but in a physical manner (refer to Eq. 1). Water losses as defined here are negative in economic sense only if the benefit in terms of foreign earning does not outweigh the costs in terms of opportunity cost and negative externalities left at the site of production.

The nations with the largest net water loss are the USA $\left(92 \mathrm{Gm}^{3} / \mathrm{yr}\right)$, Australia $\left(57 \mathrm{Gm}^{3} / \mathrm{yr}\right)$, Argentina $\left(47 \mathrm{Gm}^{3} / \mathrm{yr}\right)$, Canada $\left(43 \mathrm{Gm}^{3} / \mathrm{yr}\right)$, Brazil $\left(36 \mathrm{Gm}^{3} / \mathrm{yr}\right)$ and Thailand $\left(26 \mathrm{Gm}^{3} / \mathrm{yr}\right)$. Figure 5 shows the water losses of all countries that have a net water loss due to the production for export. The list of nations with the largest net water loss through the international trade of agricultural products is presented in Table 2 .

The main products behind the national water loss from the USA are oil-bearing crops and cereal crops. These products are partly produced rain-fed and partly irrigated. However 
Table 2. Nations with the largest net water loss as a result of international trade of agricultural products. Period 1997-2001.

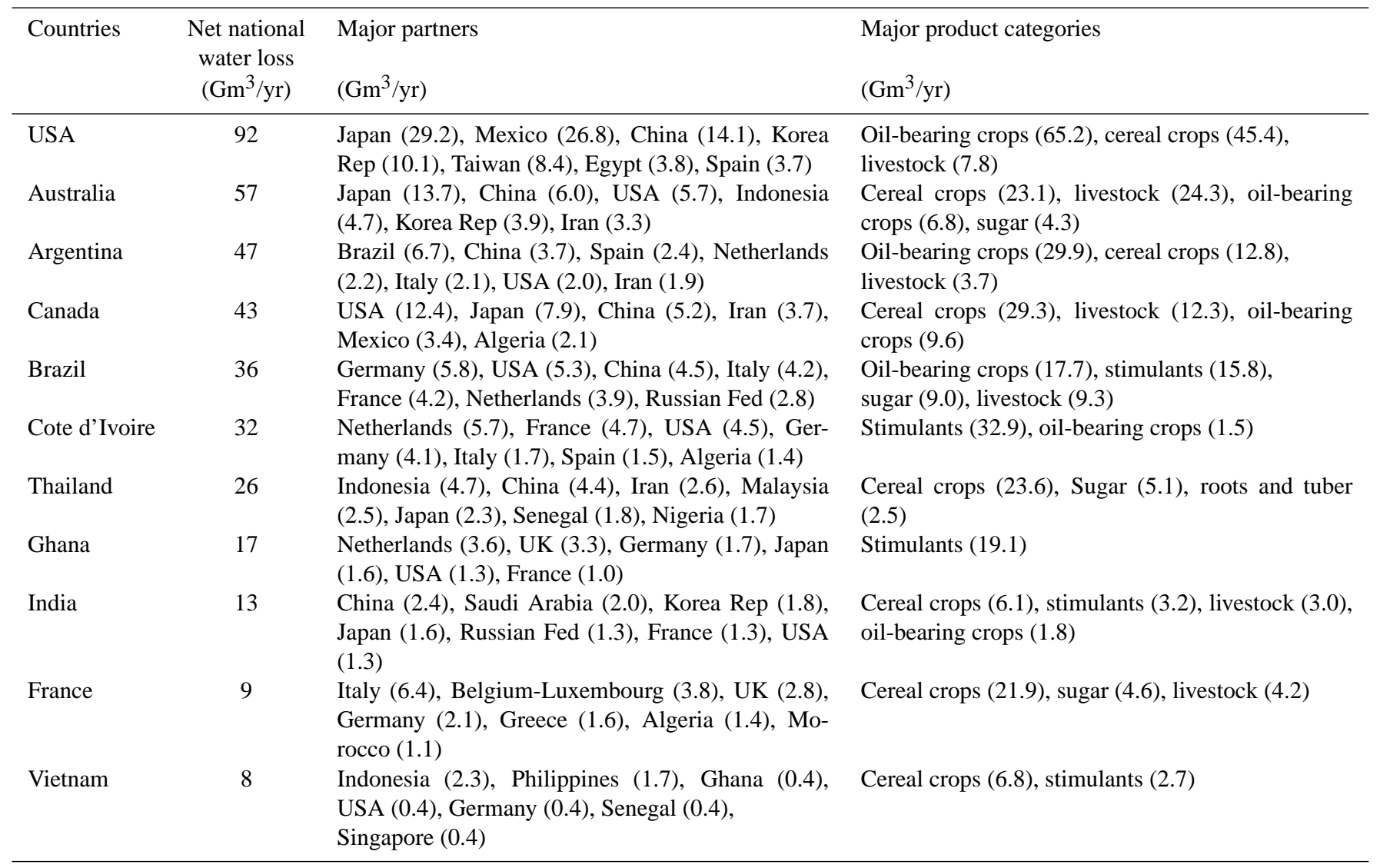

the loss from Cote d'Ivoire and Ghana is mainly from the export of stimulants, which are almost entirely rain-fed. The use of green water has no major competition with other uses in these countries. This type of loss to the national water resources is unlikely to be questionable from an economic perspective, because the opportunity costs of this water are low. The concern is limited to the environmental impacts, which are generally not included in the price of the export products.

The national water losses from France, Vietnam and Thailand are mainly the result of cereal crop products. Particularly the example of rice export from Thailand is interesting from a blue water and opportunity cost perspective (Fig. 6). Thailand exports $27.8 \mathrm{Gm}^{3} / \mathrm{yr}$ of water in the form of rice, mostly grown in the central and northern regions (Maclean et al., 2002). The monetary equivalent of rice export is 1556 million US\$/yr (ITC, 2004). Hence, from the loss of its national water, Thailand is generating foreign exchange of $0.06 \mathrm{US} \$ / \mathrm{m}^{3}$. As a considerable part of the rice cultivation in Thailand is done during the rainy season, the share of green water is quite substantial in the virtual water content of the rice. Nevertheless, irrigation is widespread, to achieve two harvests per year. If the contribution of irrigation water (blue water) is $50 \%$ to the total water use of the crop, and if other resources would have zero cost (which is clearly not the case), the value of the blue water used in rice production for export from Thailand would be $0.12 \mathrm{US} \$ / \mathrm{m}^{3}$. This number can be interpreted as the upper estimate of the value obtained from the blue water used. Since the benefits of rice export should be attributed to all the resources consumed in the production process (not just water, but also land, labour, etc.), the actual value obtained will be much less.

\section{Global water savings}

Considering the international trade flows between all major countries of the world and looking at the major agricultural products being traded (285 crop products and 123 livestock products), it has been calculated that the global water saving by trade in agricultural products is $352 \mathrm{Gm}^{3} / \mathrm{yr}$ (Table 3). This volume equals $28 \%$ of the international virtual water flows related to agricultural product trade and $6 \%$ of the global volume of water used for agricultural production (which is $6391 \mathrm{Gm}^{3} / \mathrm{yr}$, see Chapagain and Hoekstra, 2004). The trade flows that save more than $0.5 \mathrm{Gm}^{3} / \mathrm{yr}$ are shown in Fig. 7. The trade flows between USA-Japan and USA-Mexico are the biggest global water savers. The 


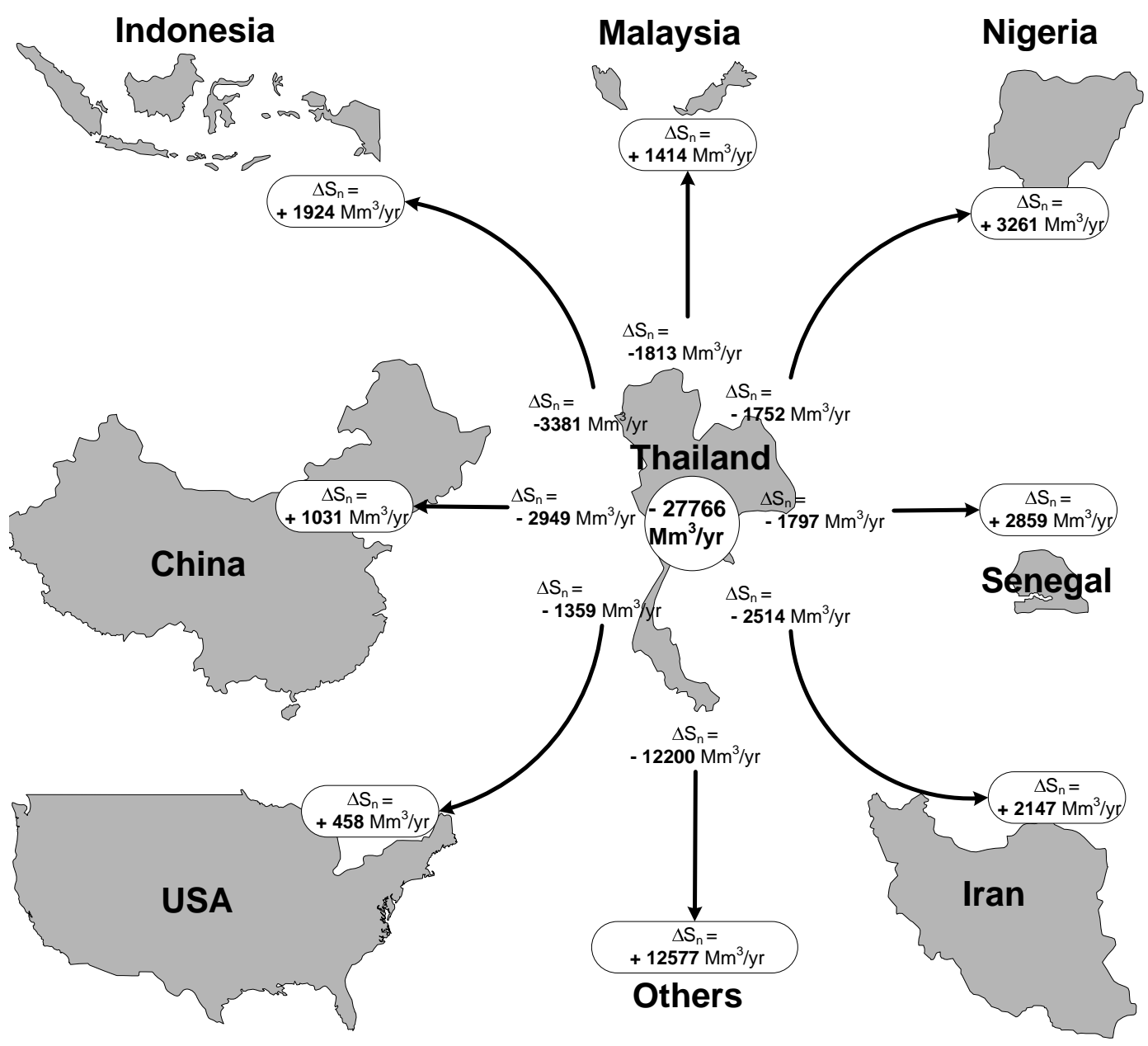

Fig. 6. National water loss related to the net rice export of Thailand. Period 1997-2001.

Table 3. Global virtual water flows and water savings. Period 1997-2001.

\begin{tabular}{|c|c|c|c|}
\hline & $\begin{array}{l}\text { Related to trade } \\
\text { of crop products } \\
\qquad\left(\mathrm{Gm}^{3} / \mathrm{yr}\right)\end{array}$ & $\begin{array}{l}\text { Related to trade of } \\
\text { livestock products } \\
\qquad\left(\mathrm{Gm}^{3} / \mathrm{yr}\right)\end{array}$ & $\begin{array}{l}\text { Total } \\
\left(\mathrm{Gm}^{3} / \mathrm{yr}\right)\end{array}$ \\
\hline $\begin{array}{l}\text { Global sum of virtual water exports, assessed } \\
\text { on the basis of the virtual water content of the } \\
\text { products in the exporting countries }\left(\mathrm{Gm}^{3 /} \mathrm{yr}\right)\end{array}$ & 979 & 275 & 1254 \\
\hline $\begin{array}{l}\text { Global sum of virtual water imports, assessed } \\
\text { on the basis of the virtual water content of } \\
\text { products if produced in the importing countries } \\
\left(\mathrm{Gm}^{3 /} \mathrm{yr}\right)\end{array}$ & 1286 & 320 & 1646 \\
\hline Global water saving $\left(\mathrm{Gm}^{3 /} \mathrm{yr}\right)$ & 307 & 45 & 352 \\
\hline $\begin{array}{l}\text { Saving compared to the sum of international } \\
\text { virtual water flows }(\%)\end{array}$ & $34 \%$ & $16 \%$ & $30 \%$ \\
\hline $\begin{array}{l}\text { Saving compared to the global water use for } \\
\text { agricultural products }(\%)\end{array}$ & $5.3 \%$ & $0.7 \%$ & $6 \%$ \\
\hline
\end{tabular}




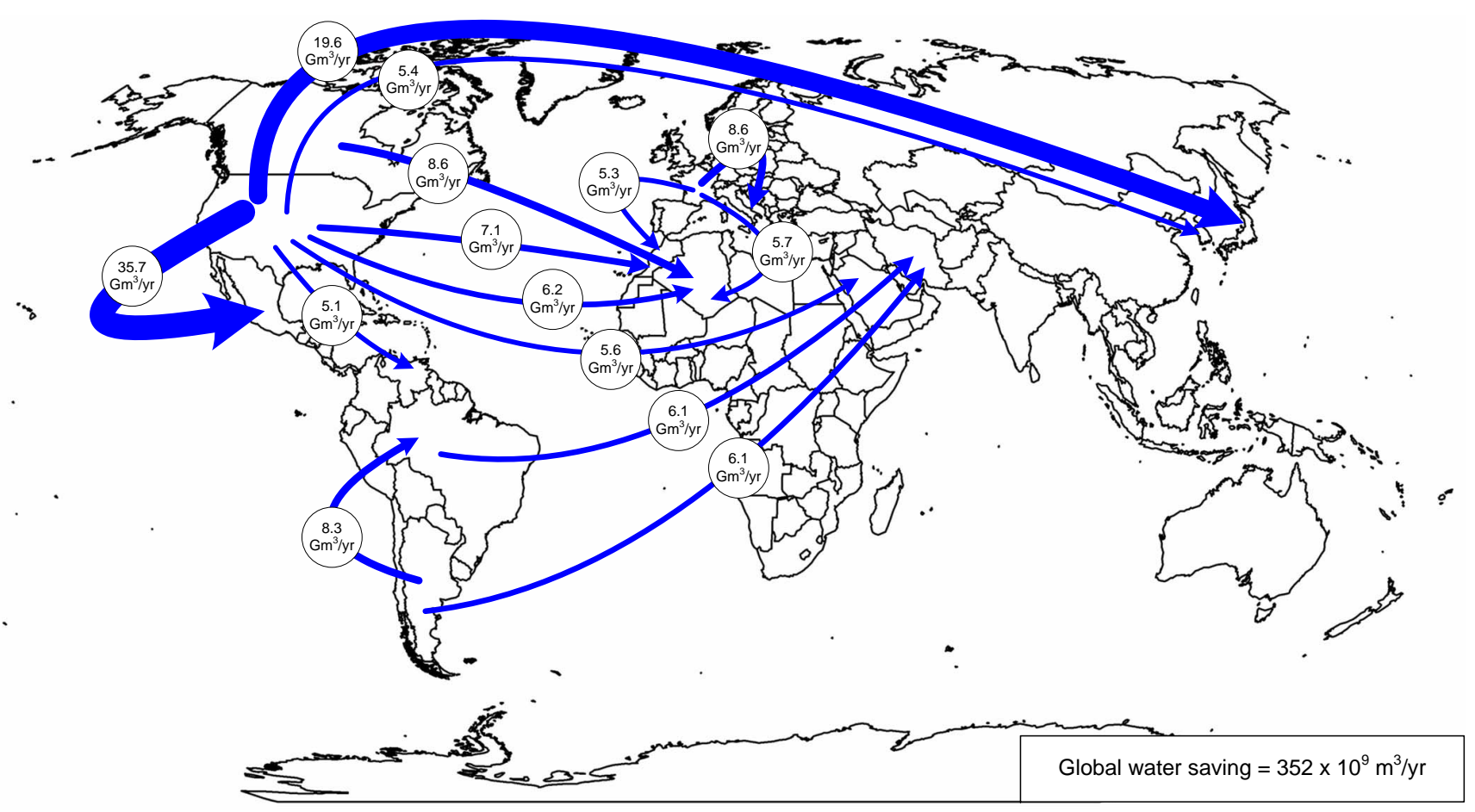

Fig. 7. Global water savings $\left(>5.0 \mathrm{Gm}^{3} / \mathrm{yr}\right)$ associated with international trade of agricultural products. Period $1997-2001$.

contribution of different product groups to the total global water saving is presented in Fig. 8. Cereal crop products form the largest group responsible for the total global water saving, with a saving of $222 \mathrm{Gm}^{3} / \mathrm{yr}$, followed by oilbearing crops $\left(68 \mathrm{Gm}^{3} / \mathrm{yr}\right.$, mainly soybeans) and livestock products $\left(45 \mathrm{Gm}^{3} / \mathrm{yr}\right)$. The cereal group is composed of wheat $\left(103 \mathrm{Gm}^{3} / \mathrm{yr}\right)$, maize $\left(68 \mathrm{Gm}^{3} / \mathrm{yr}\right)$, rice $\left(21 \mathrm{Gm}^{3} / \mathrm{yr}\right)$, barley $\left(21 \mathrm{Gm}^{3} / \mathrm{yr}\right)$, and others $\left(9 \mathrm{Gm}^{3} / \mathrm{yr}\right)$.

The largest global water savings by wheat trade are occurring as a result of wheat import in the Middle East and North African from Western Europe and North America. Figure 9 shows the wheat trade flows saving more than $2 \mathrm{Gm}^{3}$ of water per year. Maize imports in Japan alone are responsible for $15 \mathrm{Gm}^{3} / \mathrm{yr}$ of global water saving. The global saving of water as a result of maize trade is mainly from the export of maize from USA. Figure 10 shows the maize trade flows saving more than $1 \mathrm{Gm}^{3} / \mathrm{yr}$. Figure 11 shows the global water savings above $0.5 \mathrm{Gm}^{3} / \mathrm{yr}$ as a result of rice trade. As the production is more favourable (climate and culture) in South-east Asia, the largest savings are from the export from this region to the Middle East and West Africa. The major saving through the trade of rice is between Thailand-Iraq, Thailand-Nigeria, Syria-Nigeria, and China-Indonesia.

Considering the import of wheat in Egypt, one can see that this contributes to global water saving in some cases and global water loss in other cases (Fig. 4). The import from USA, France and Argentina is globally saving water by $0.23 \mathrm{Gm}^{3} / \mathrm{yr}$, whereas the import of wheat from Canada, Turkey and Australia results in a global water loss of $0.58 \mathrm{Gm}^{3} / \mathrm{yr}$. Though Egypt's import of wheat saves national water resources by $3.6 \mathrm{Gm}^{3} / \mathrm{yr}$, it results in a net global water loss of $0.4 \mathrm{Gm}^{3} / \mathrm{yr}$. The crop water requirement in Egypt is relatively high compared to its trading partners, but this is partially compensated by a relatively high wheat yield, which is more than twice the global average (Table 4). As a result, water productivity (water use per unit of product) in wheat production in Egypt is higher than in Canada, Turkey and Australia. However, wheat production in Egypt is using scarce blue water resources and the partner countries are making use of the effective rainfall (green water). The net global water loss related to the wheat export from Canada etc. to Egypt results from the fact that the volume of blue water resources that would have been required in Egypt to produce domestically is smaller than the volume of green water resources actually used in Canada etc. Blue and green water resources fundamentally differ in terms of possible application and thus opportunity cost. For further analysis and interpretation of figures on global water savings or losses it is thus important to split up these figures into a blue and green water component.

A second example elaborated here is the trade of maize from the USA to Japan. The global water saving from this trade is $15.4 \mathrm{Gm}^{3} / \mathrm{yr}$. The evaporative demand of maize in Japan $(367 \mathrm{~mm} /$ crop period) is comparable with that in the 


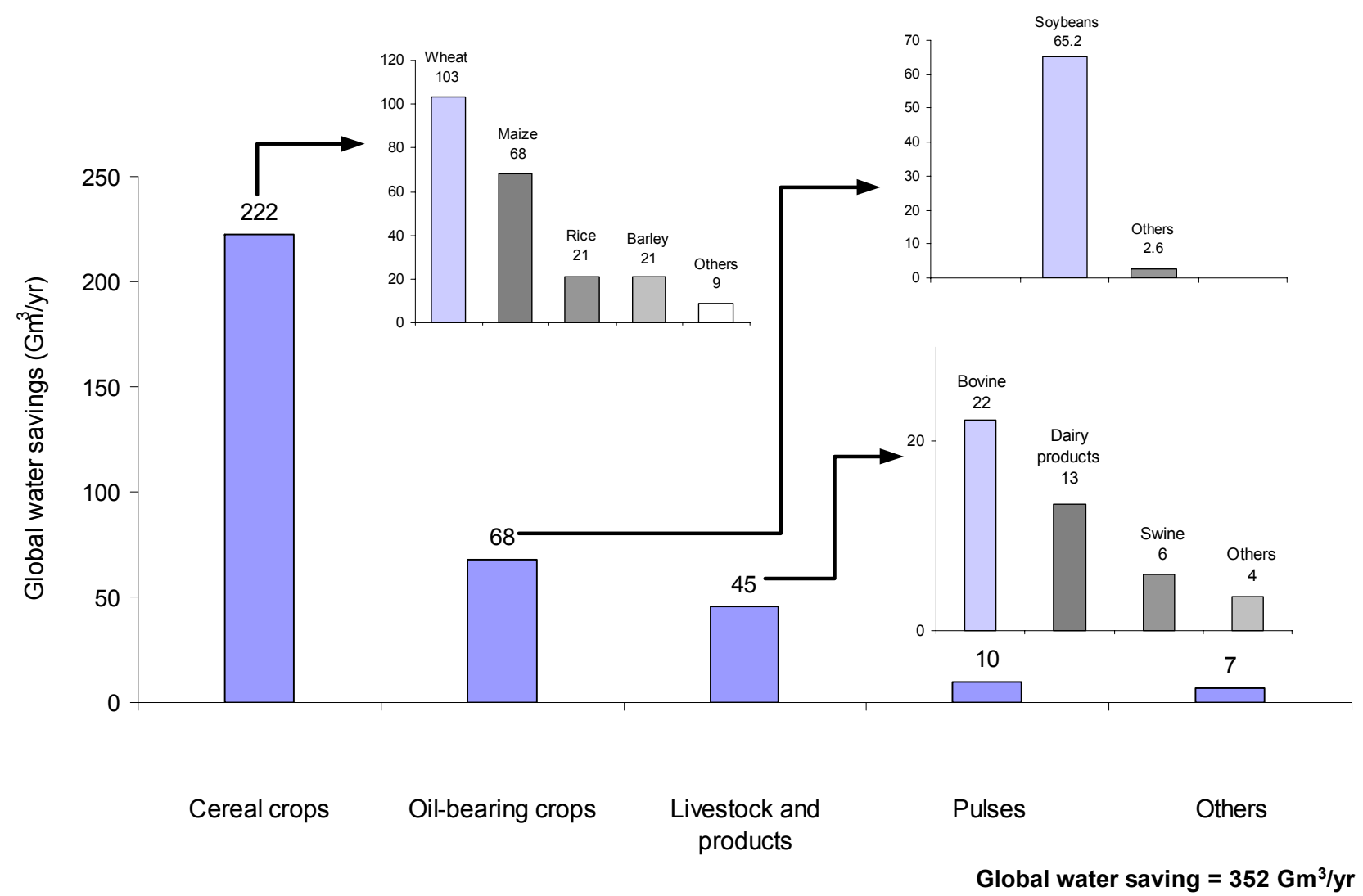

Fig. 8. Global water savings ( $\left.\mathrm{Gm}^{3} / \mathrm{yr}\right)$ per traded product category. Period 1997-2001.

Table 4. Crop water requirements, crop yields and the virtual water content of wheat in Egypt and its major trade partners. Period 19972001.

\begin{tabular}{|c|c|c|c|}
\hline & $\begin{array}{c}\text { Crop water } \\
\text { requirement } \\
(\mathrm{mm} / \text { crop period })\end{array}$ & $\begin{array}{l}\text { Wheat yield } \\
\text { (ton/ha) }\end{array}$ & $\begin{array}{c}\text { Virtual water } \\
\text { content } \\
\left(\mathrm{m}^{3} / \text { ton }\right)\end{array}$ \\
\hline Argentina & 179 & 2.4 & 738 \\
\hline Australia & 309 & 1.9 & 1588 \\
\hline Canada & 339 & 2.3 & 1491 \\
\hline Egypt & 570 & 6.1 & 930 \\
\hline France & 630 & 7.0 & 895 \\
\hline Turkey & 319 & 2.1 & 1531 \\
\hline USA & 237 & 2.8 & 849 \\
\hline Global average & & 2.7 & 1334 \\
\hline
\end{tabular}

USA (411 mm/crop period), but the crop yield in the USA (8.4 ton/ha) is significantly higher than in Japan (2.5 ton/ha), so that the virtual water content of maize in Japan is 3 times higher than in the USA. Saving domestic water resources is not the only positive factor for Japan. If Japan would like to grow the quantity of maize which is now imported from the USA, it would require 6 million hectare of additional cropland. This is a lot given the scarcity of land in Japan.
Table 5. Crop water requirements, crop yields and the virtual water content of rice in Thailand and its major trade partners. Period 1997-2001.

\begin{tabular}{lccc}
\hline & $\begin{array}{c}\text { Crop water } \\
\text { requirement } \\
(\mathrm{mm} / \text { crop period })\end{array}$ & Rice yield & $\begin{array}{c}\text { Virtual water } \\
\text { content } \\
\left(\mathrm{m}^{3} / \text { ton }\right)\end{array}$ \\
\hline China & 830 & 6.3 & 1321 \\
Indonesia & 932 & 4.3 & 2150 \\
Iran & 1306 & 4.1 & 3227 \\
Malaysia & 890 & 3.0 & 2948 \\
Nigeria & 1047 & 1.5 & 7036 \\
Senegal & 1523 & 2.5 & 6021 \\
Thailand & 945 & 2.5 & 3780 \\
USA & 863 & 6.8 & 1275 \\
Global average & & 3.9 & 2291 \\
\hline
\end{tabular}

A third case considered here is rice export from Thailand. Though Thailand looses water by exporting to Nigeria and Senegal by $1.7 \mathrm{Gm}^{3} / \mathrm{yr}$ and $1.8 \mathrm{Gm}^{3} / \mathrm{yr}$ respectively, it is saving water globally as the national water savings in Nigeria $\left(3.2 \mathrm{Gm}^{3} / \mathrm{yr}\right)$ and Senegal $\left(2.9 \mathrm{Gm}^{3} / \mathrm{yr}\right)$ are higher than the losses in Thailand (Fig. 6). The main reason behind the 


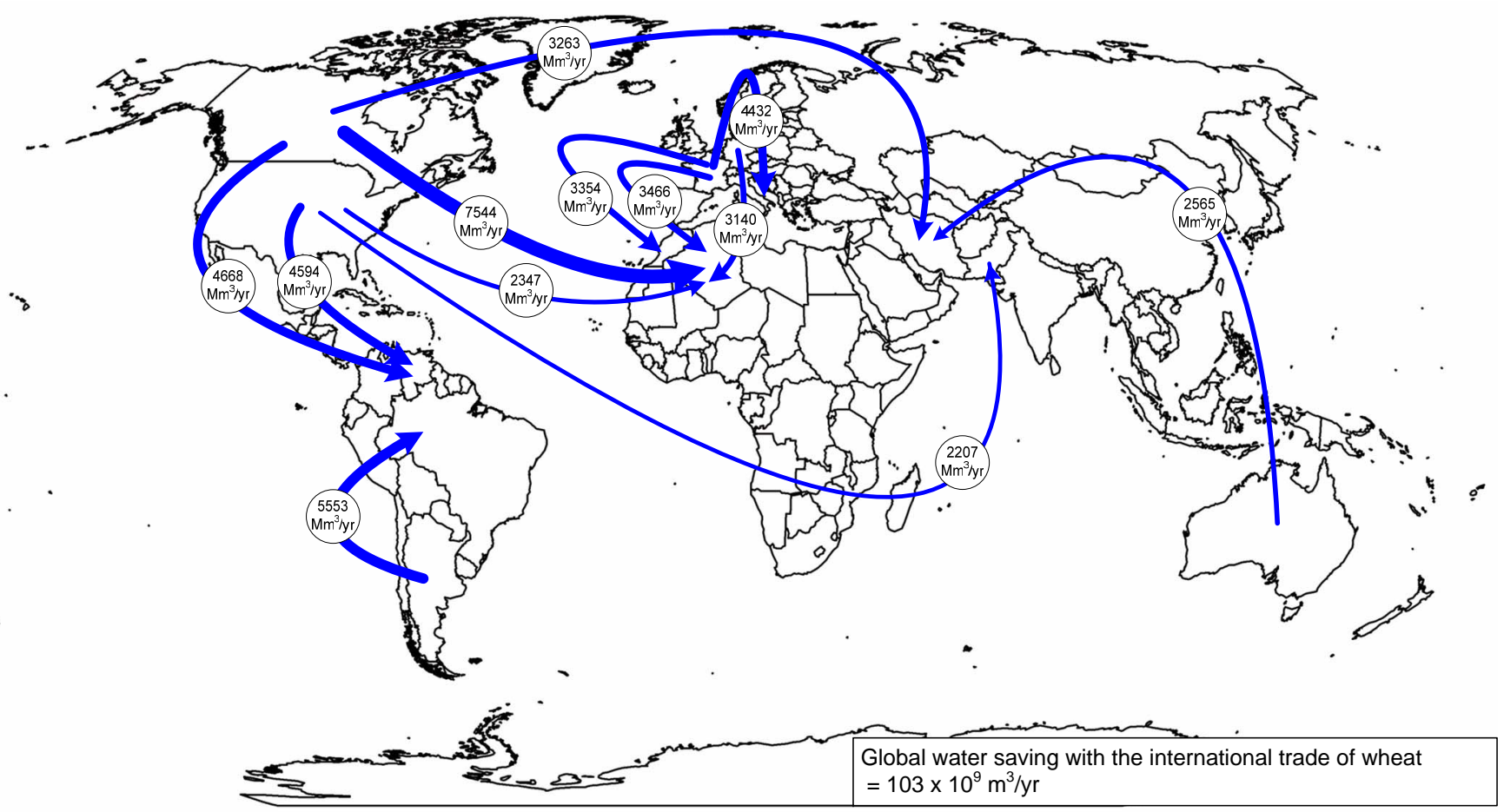

Fig. 9. Global water savings $\left(>2.0 \mathrm{Gm}^{3} / \mathrm{yr}\right.$ ) associated with the international trade of wheat. Period 1997-2001.

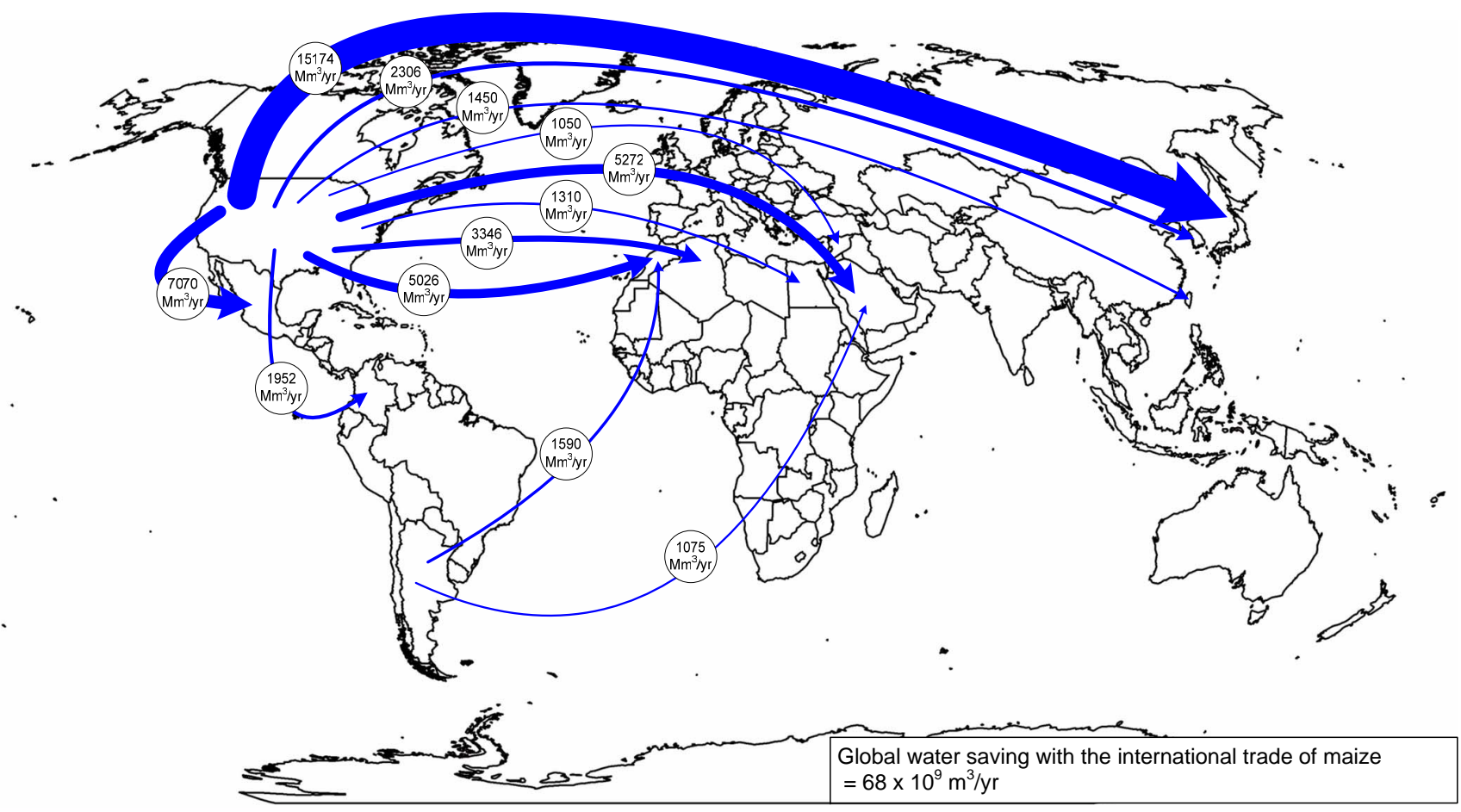

Fig. 10. Global water savings $\left(>1.0 \mathrm{Gm}^{3} / \mathrm{yr}\right)$ associated with the international trade of maize. Period 1997-2001. 


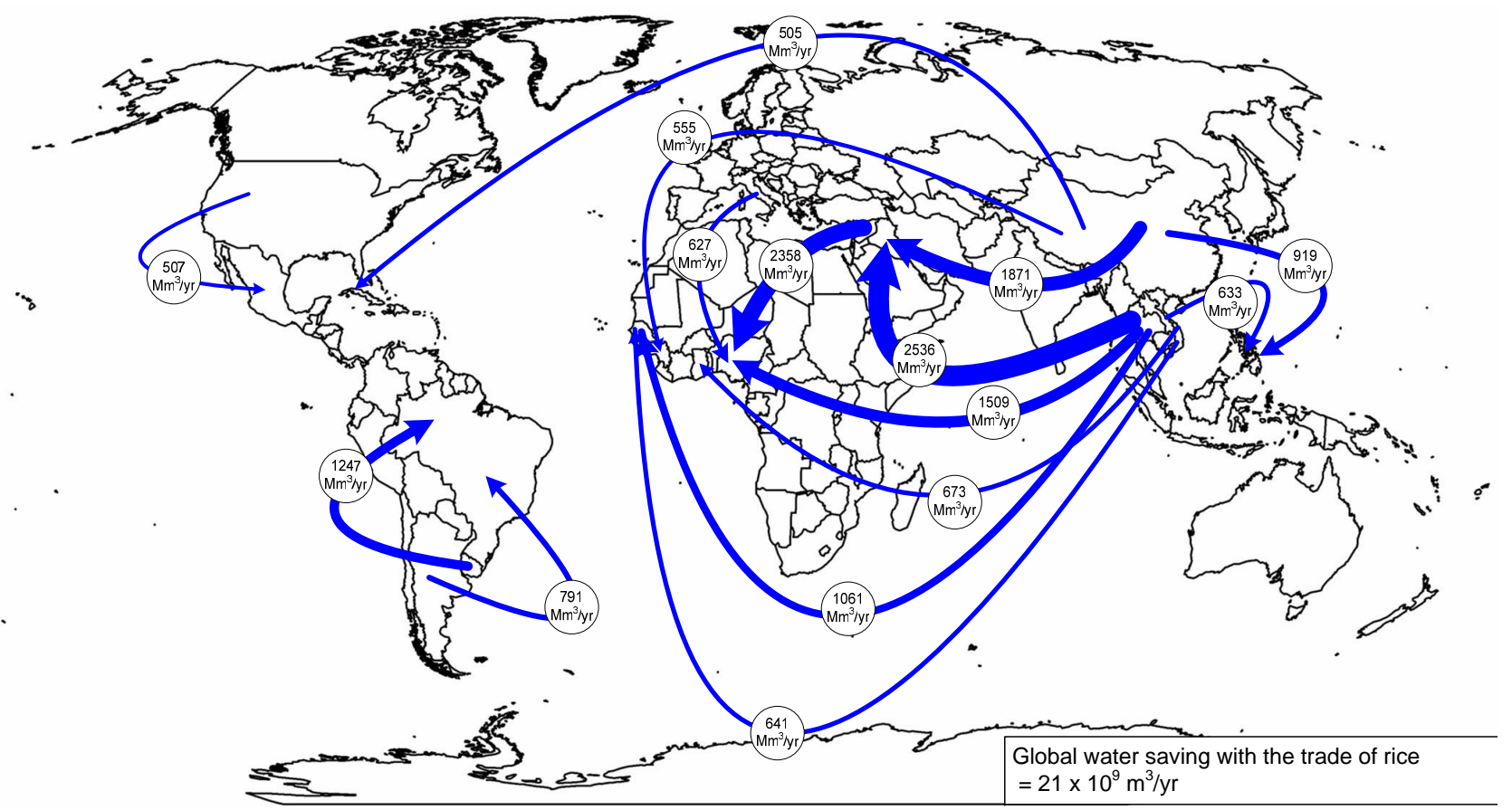

Fig. 11. Global water savings $\left(>0.5 \mathrm{Gm}^{3} / \mathrm{yr}\right)$ associated with the international trade of rice. Period 1997-2001.

global saving related to the trade between Thailand and Nigeria, is that rice yield in Thailand is 1.7 times higher than in Nigeria (Table 5). These two countries have crop water requirements of comparable magnitude $(1000 \mathrm{~mm} / \mathrm{crop}$ period). On the contrary, the main reason behind the global water saving by the trade between Thailand and Senegal, which both have a crop yield in the order of 2.5 ton/ha, is the difference in the crop water requirements in Thailand (945 mm/crop period) and Senegal (1523 mm/crop period). The export of rice from Thailand to five other trading partners (China, Indonesia, Iran, Malaysia and USA) is creating a global water loss of $5 \mathrm{Gm}^{3} / \mathrm{yr}$. National water loss in Thailand is greater than the corresponding national water savings in these countries. This is due to the fact that rice yield in Thailand is low if compared to the countries where it exports to.

\section{Global blue water savings at the cost of green water losses}

The global water saving $\Delta S_{g}$ is made up of a global blue water saving $\left(\Delta S_{g, b}\right)$ and a global green water saving $\left(\Delta S_{g, g}\right)$ component:

$$
\begin{aligned}
\Delta S_{g} & =T \times\left(V_{i}-V_{e}\right) \\
& =T \times\left(\left(V_{g, i}+V_{b, i}\right)-\left(V_{g, e}+V_{b, e}\right)\right) \\
& =T \times\left(V_{g, i}-V_{g, e}\right)+T \times\left(V_{b, i}-V_{b, e}\right) \\
& =\Delta S_{g, g}+\Delta S_{g, b}
\end{aligned}
$$

Even if there is a net global water loss from a trade relation, there might be a saving of blue water at the cost of a greater loss of green water or vice versa. The case is elaborated with the example of Egypt's wheat trade. The virtual water content of wheat in Egypt is $930 \mathrm{~m}^{3} / \mathrm{ton}$. This is all blue water; the green component of the virtual water content of wheat is zero. Suppose that Egypt is importing $T$ ton/yr of wheat from Australia. The virtual water content of wheat in Australia is $1588 \mathrm{~m}^{3} /$ ton. Wheat production in Australia is not $100 \%$ irrigated; it is assumed here that a fraction $f$ of the virtual water content of wheat in Australia is green water. There is net global loss of $658 T \mathrm{~m}^{3} / \mathrm{yr}$ in this trade.

$$
\begin{aligned}
\Delta S_{g} & =T \times\left(V_{i}-V_{e}\right) \\
& =T \times(930-1588) \\
& =-658 T
\end{aligned}
$$

The global green water saving, $\Delta S_{g, g}\left(\mathrm{~m}^{3} / \mathrm{yr}\right)$, in this case is always negative:

$$
\begin{aligned}
\Delta S_{g, g} & =T \times\left(V_{g, i}-V_{g, e}\right) \\
& =T \times(0-f \times 1588) \\
& =-T \times 1588 f
\end{aligned}
$$

However, whether the global blue water saving $\Delta S_{g, b}$ $\left(\mathrm{m}^{3} / \mathrm{yr}\right)$ is positive or negative depends upon the fraction $f$ in the exporting country:

$$
\begin{aligned}
\Delta S_{g, b} & =T \times\left(V_{b, i}-V_{b, e}\right) \\
& =T \times(930-(1-f) 1588) \\
& =T \times(-658+1588 f)
\end{aligned}
$$


There is net gain in global blue water resources as long as the blue water component of Australian wheat is smaller than in Egypt, i.e. if the fraction $f$ in Australia is larger than 0.42. In a case of extreme drought, if the effective rainfall in Australia for wheat is zero $(f=0)$ and all the evaporative demand is met by irrigation, all the losses are in blue water resources, which is $658 \mathrm{~T} \mathrm{~m}^{3} / \mathrm{yr}$. In another extreme example, when the full evaporative demand of wheat in Australia is met by effective rainfall, so that no irrigation water is used $(f=1)$, the global loss of green water will be $1588 \mathrm{~T}$, but we obtain a net global gain of blue water of $930 \mathrm{~T} \mathrm{~m}^{3} / \mathrm{yr}$. Here, the gain in blue water is obtained at the cost of green water.

Since blue water resources are generally scarcer than green water resources, global water losses can be positively evaluated if still blue water resources are being saved. The classical example of trade that makes sense from both water resources and economic point of view is when predominantly rain-fed crop or livestock products from humid areas are imported into a country where effective rainfall is negligible. Also the import of products that originate from semi-arid countries that apply supplementary irrigation can be beneficial from a global point of view, because supplementary irrigation increases yields often more than double, a profitable situation that can never be achieved in arid countries where effective rainfall is too low to allow for supplementary irrigation, so that full irrigation is the only option.

\section{Discussion}

The volume of global water saving from the international trade of agricultural products is $352 \mathrm{Gm}^{3} / \mathrm{yr}$ (average over the period 1997-2001). The largest savings are from international trade of crop products, mainly cereals $\left(222 \mathrm{Gm}^{3} / \mathrm{yr}\right)$ and oil crops $\left(68 \mathrm{Gm}^{3} / \mathrm{yr}\right)$, owing to the large regional differences in virtual water content of these products and the fact that these products are generally traded from water efficient to less water efficient regions. Since there is smaller variation in the virtual water content of livestock products, the savings by trade of livestock products are less.

The export of a product from a water efficient region (relatively low virtual water content of the product) to a water inefficient region (relatively high virtual water content of the product) saves water globally. This is the physical point of view. Whether trade of products from water efficient to water inefficient countries is beneficial from an economic point of view, depends on a few additional factors, such as the character of the water saving (blue or green water saving), and the differences in productivity with respect to other relevant input factors such as land and labour. Besides, international trade theory tells that it is not the absolute advantage of a country that indicates what commodities to produce but the relative advantage (Wichelns, 2004). The decision to produce locally or to import from other sites should be made on the basis of the marginal value or the utility of the water being saved at the consumption site compared to the cost of import.

Saving domestic water resources in countries that have relative water scarcity by the mechanism of virtual water import (import of water-intensive products) looks very attractive. There are however a number of drawbacks that have to be taken into account as well. Saving domestic water through import should explicitly be seen in the context of:

- the need to generate sufficient foreign exchange to import food which otherwise would be produced domestically;

- the risk of moving away from food self sufficiency that associates with the fear of being held to political ransom;

- increased urbanization in importing countries as import reduces employment in the agricultural sector;

- reduced access of the poor to food; and

- increased risk of environmental impact in exporting countries, which is generally not accounted for in the price of the imported products.

Enhanced virtual water trade to optimise the use of global water resources can relieve the pressure on water scarce countries but may create additional pressure on the countries that produce the water-intensive commodities for export. The potential water saving from global trade is only sustainable if the prices of the export commodities truly reflect the opportunity costs and negative environmental externalities in the exporting countries. Otherwise the importing countries simply gain from the fact that they would have to bear the cost of water depletion if they would produce domestically whereas the costs remain external if they import the water-intensive commodities instead.

Since an estimated $16 \%$ of the global water use is not for domestic consumption but for export, global water use efficiency becomes an important issue with increasing globalisation of trade. Though international trade is seldom done to enhance global water productivity, there is an urgent need to address the increasing global water scarcity problem.

Edited by: P. van der Zaag

\section{References}

Allan, J. A.: Water Stress and Global Mitigation: Water, Food and Trade, Arid Land Newsletter, 45, 1999.

Allen, R. G., Pereira, L. S., Raes, D., and Smith, M.: Crop evapotranspiration - Guidelines for computing crop water requirements, FAO, Rome, 1998.

Chapagain, A. K. and Hoekstra, A. Y.: Virtual water flows between nations in relation to trade in livestock and livestock products, Value of Water Research Report Series No. 13, UNESCO-IHE, Delft, the Netherlands, 2003. 
Chapagain, A. K. and Hoekstra, A. Y.: Water footprints of nations, Value of Water Research Report Series No. 16, UNESCO-IHE, Delft, the Netherlands, 2004.

De Fraiture, C., Cai, X., Amarasinghe, U., Rosegrant, M. and Molden, D.: Does international cereal trade save water? The impact of virtual water trade on global water use, Comprehensive Assessment Research Report 4, IWMI, Colombo, 2004.

FAO: Technical Conversion Factors for Agricultural Commodities, Food and Agriculture Organization, Rome, 2003.

FAO: CLIMWAT database, Food and Agriculture Organization, Rome, http://www.fao.org/ag/AGL/aglw/climwat.stm, 2004a.

FAO: Review of global agricultural water use per country, Food and Agriculture Organization, Rome, http://www.fao.org/ landandwater/aglw/aquastat/water_use/index5.stm, 2004b.

FAO: FAOSTAT on-line database, Food and Agriculture Organization, Rome, http://apps.fao.org/default.jsp, 2004c.

Greenaway, F., Hassan, R. and Reed, G. V.: An empirical analysis of comparative advantage in Egyptian agriculture, Appl. Eco., 26, 649-657, 1994.

Hoekstra, A. Y. (Ed.): Virtual water trade: Proceedings of the International Expert Meeting on Virtual Water Trade, Value of Water Research Report Series No. 12, UNESCO-IHE, Delft, The Netherlands, 2003.

Hoekstra, A. Y. and Hung, P. Q.: Virtual water trade: a quantification of virtual water flows between nations in relation to international crop trade, Value of Water Research Report Series No. 11, UNESCO-IHE, Delft, The Netherlands, 2002.

Hoekstra, A. Y. and Hung, P. Q.: Globalisation of water resources: International virtual water flows in relation to crop trade, Global Environmental Change, 15(1), 45-56, 2005.

ITC: PC-TAS version 1997-2001 in HS or SITC, CD-ROM, International Trade Centre, Geneva, 2004.

Maclean, J. L., Dawe, D. C., Hardy, B., and Hettel, G. P.: Rice almanac: Source book for the most important economic activity on earth, International Rice Research Institute, Los Baños, Philippines, 2002.
Mitchell, T.: TYN CY 1.1, Tyndall Centre for Climate Change Research, Climatic Research Unit, University of East Anglia, UK, http://www.cru.uea.ac.uk/ timm/cty/obs/TYN_CY_1_ 1.html, 2004.

Oki, T. and Kanae, S.: Virtual water trade and world water resources, Water Science \& Technology, 49(7), 203-209, 2004.

Oki, T., Sato, M., Kawamura, A., Miyake, M., Kanae, S., and Musiake, K.: Virtual water trade to Japan and in the world, in: Virtual water trade: Proceedings of the International Expert Meeting on Virtual Water Trade, Value of Water Research Report Series No. 12, edited by: Hoekstra, A. Y., UNESCO-IHE, Delft, The Netherlands, 221-235, 2003.

Renault, D.: Value of virtual water in food: Principles and virtues, n: Virtual water trade: Proceedings of the International Expert Meeting on Virtual Water Trade, Value of Water Research Report Series No. 12, edited by: Hoekstra, A. Y., UNESCO-IHE, Delft, The Netherlands, 77-91, 2003.

Wichelns, D.: The role of 'virtual water' in efforts to achieve food security and other national goals, with an example from Egypt, Agricultural Water Management, 49(2), 131-151, 2001.

Wichelns, D.: The policy relevance of virtual water can be enhanced by considering comparative advantages, Agricultural Water Management, 66(1), 49-63, 2004.

Yang, H., Reichert, P., Abbaspour, K. C., and Zehnder, A. J. B.: A water resources threshold and its implications for food security, in: Virtual water trade: Proceedings of the International Expert Meeting on Virtual Water Trade' Value of Water Research Report Series No. 12, edited by: Hoekstra, A. Y., UNESCO-IHE, Delft, The Netherlands, 111-117, 2003.

Zimmer, D. and Renault, D.: Virtual water in food production and global trade: Review of methodological issues and preliminary results, in: Virtual water trade: Proceedings of the International Expert Meeting on Virtual Water Trade, Value of Water Research Report Series No. 12, edited by: Hoekstra, A. Y., UNESCO-IHE, Delft, The Netherlands, 93-109, 2003. 